\title{
Peningkatan Hasil Belajar Mengenal Sandhangan Aksara Jawa Melalui Model Flipped Classroom Berbantu Media Powerpoint Interaktif Kelas IV SD
}

\author{
Himmatul Ulya \\ Universitas Sebelas Maret \\ Himmatululya28@gmail.com
}

\section{Article History}

received 30/4/2021

revised 30/5/2021

accepted 30/6/2021

\begin{abstract}
The problems found are the low learning outcomes of students in recognizing the Javanese script. The purpose of the study was to determine the increase in learning outcomes to recognize Javanese script through themodel Flipped Classroom assisted bymedia Powerpoint Interactivein fourth grade students of SD Negeri Mranggen 1 for the 2020/2021 academic year. The method used is classroom action research with the subject of this research, namely 25 students in class IV SD Negeri Mranggen 1 for the 2020/2021 academic year. Data collection techniques are documentation, tests and observations with quantitative description analysis techniques and qualitative descriptions. The percentage of classical completeness in preaction was $40 \%$ with an average of 58.8. Cycle I average value of 73.4 with a classical completeness of $68 \%$ Cycle II an average value of 76.8 with a percentage of classical completeness of $76 \%$. Cycle III the average value of 80.2 with a percentage of $88 \%$ classical conclusions of the research results that through the model Flipped Classroom media PowerPoint-assisted interactivecan improve learning outcomes in sandhangan Aksara Java for the fourth grade student of SD Negeri Mranggen 1 for 2020/2021 academy year.

Keywords: Flipped Classroom, Interactive Powerpoint, Learning Outcomes Javanese Script
\end{abstract}

\begin{abstract}
Abstrak
Permasalahan yang ditemukan rendahnya hasil belajar peserta didik pada dalam mengenal sandhangan aksara jawa. Tujuan penelitian ialah mengetahui peningkatan hasil belajar mengenal sandhangan aksara jawa melalui model Flipped Classroom berbantu media Powerpoint Interaktif pada peserta didik kelas IV SD Negeri Mranggen 1 Tahun Ajaran 2020/2021. Metode yang dilakukan ialah penelitian tindakan kelas dengan subjek penelitian ini yaitu 25 peserta didik pada kelas IV SD Negeri Mranggen 1 Tahun Ajaran 2020/2021. Teknik pengumpulan data yaitu dokumentasi, tes dan observasi dengan teknik analisis diskripsi kuantitatif dan deskripsi kualitatif. Presentasen ketuntasan klasikal dalam pratindakan sebesar $40 \%$ dengan rata-rata 58,8 . Siklus I nilai rata-rata sebesar 73,4 dengan ketuntasan klasikal sebesar $68 \%$ Siklus II nilai rata-rata 76,8 dengan presentase ketuntasan klasikal sebesar $76 \%$. Siklus III nilai rata-rata 80,2 dengan presentase klasikal sebesar $88 \%$ Simpulan dari hasil penelitian bahwa melalui model Flipped Classroom berbantu media powerpoint interaktif dapat meningkatkan hasil belajar dalam mengenal sandhangan aksra jawa pada peserta didik Kelas IV SD Negeri Mranggen 1 Tahun Ajaran 2020/2021.
\end{abstract}

Kata Kunci : Flipped Classroom, Powerpoint Interaktif, Hasi belajar Aksara Jawa 


\section{PENDAHULUAN}

Pada Peraturan Daerah Jawa Tengah No. 9 tahun 2012 menyatakan bahwa bahasa jawa sebagai muatan lokal kurikulum 2013 yang wajib diajarkan pada sekolah formal, informal dan nonformal disamping muatan lokal lainnya. Dalam pelaksanaannya, pembelajaran Bahasa Jawa menjadi muatan mata pelajaran yang terpisah dari muatan pembelajaran lainnya. Bahasa Jawa merupakan suatu bahasa daerah yang merupakan bagian dari kebudayaan nasional. Pada kegiatan pendidikan, bahasa jawa merupakan suatu muatan pembelajaran yang diharapkan dapat melestarikan budaya setempat khususnya Jawa Tengah. Selain itu, mata pelajaran Bahasa Jawa digunakan sebagai media dalam mengajarkan budi pekerti yang luhur kepada peserta didik. Pada pembelajaran Bahasa Jawa terdapat muatan materi mengenai aksara jawa. Aksara jawa merupakan tulisan kuno yang memiliki makna. Pada peraturan daerah no.9 Tahun 2012 pada pasal 1 ayat 13 mengartikan aksara jawa sebagai carakan atau huruf yang mempunyai bentuk, tanda grafis, sistem, dan tatanan penulisan yang digunakan untuk bahasa dan sastra Jawa dalam perkembangan sejarahnya.

Berkaitan dengan kegiatan pembelajaran aksara jawa kelas IV terdapat permasalahan berupa rendahnya hasil belajar peserta didik dalam mengenal sandhangan aksra jawa. Hasil belajar merupakan perubahan yang terjadi pada diri peserta didik, baik yang menyangkut aspek kognitif, afektif, dan psikomotor sebagai hasil dari belajar (Susanto, 2013: 5). Dari ketiga ranah tersebut, ranah kognitiflah yang paling banyak dinilai sebab berhubungan dengan kemampuan dan pemahaman peserta didik dalam menguasai materi pembelajaran. Pada ranah kognitif muatan pelajaran bahasa jawa pada SD Negeri Mranggen 1 memiliki Kriteria Ketuntas Minimum (KKM) sebesar 70. Dari KKM tersebut ditemukan bahwa hasil belajar mengenal sandhangan aksara jawa dari 25 peserta didik hanya 10 peserta didik yang dinyatakan tuntas memenuhi kriteria KKM dan 15 peserta didik belum memenuhi KKM dalam aspek ranah kognitif / pengetahuan. Hal ini disebakan karena kurangnya minat peserta didik, kurangnya bahan ajar dan media pembelajaran mengenai aksara jawa dan pertemuan pembelajaran yang hanya menitikkan dua jam pembelajaran dalam seminggu yang mengakibatkan peserta didik mudah lupa mengenai materi yang telah diajarkan. Sebagai facilitator learning, dalam hal ini guru dituntut untuk mampu mengelola seluruh proses kegiatan pembelajaran secara kreatif yang dapat menciptakan kondisi-kondisi belajar sedemikian rupa sehingga pembelajaran dapat dilakukan secara efisien, efektif dan memberikan kebermaknaan belajar bagi peserta didik.

Model pembelajaran flipped classrom merupakan model pembelajaran yang mengintegrasikan pembelajaran dirumah dan pembelajaran dikelas Model pembelajaran flipped classroom adalah model dimana dalam proses belajar mengajar tidak seperti pada umumnya, yaitu dalam proses belajarnya peserta didik mempelajari materi pelajaran di rumah sebelum kelas dimulai dan kegiatan belajar mengajar di kelas berupa mengerjakan tugas, berdiskuasi tentang materi atau masalah yang belum dipahami peserta didik (Yulietri, 2015). Bagi sekolah dasar pembelajaran bahasa jawa diterapkan pada seluruh tingkatan kelas yaitu mulai dari kelas I hingga kelas VI. Pada teori Jean Piaget bahwa anak usia sekolah dasar (7-11 tahun) dalam tingkatan operasional konkret. Penggunaan media pembelajaran sangat dibutuhkan untuk memudahkan peserta didik dalam penyerapan materi pembelajaran yang disampaikan oleh guru. dimana tingkatan ini merupakan permulaan dalam berfikir rasional. Penggunaan media pembelajaran sangat dibutuhkan untuk memudahkan peserta didik dalam penyerapan materi pembelajaran yang disampaikan oleh guru. Hal ini didukung dari teori Jean Piaget dalam Dahar (2011:138) menyatakan bahwa anak usia sekolah dasar (7-11 tahun) dalam tingkatan operasional konkret. Menurut Arsyad (2014:29) manfaat dari media pembelajaran tidak hanya sebagai penyampaian informasi namun juga dapat meningkatkan dan mengarahkan perhatian peserta didik sehingga menimbulkan 
motivasi belajar, interaksi peserta didik, dan menimbulkan kemandirian belajar peserta didik yang sesuai dengan kemampuan dan minatnya.

Berdasarkan permasalahan yang ada dilapangan tersebut, maka sebagai seorang pendidik perlu berinovasi untuk mengembangkan perencanaan pembelajaran yang dapat meningkatkan hasil belajar mengenal sandhangan aksara jawa. Sehingga dalam hal ini guru berinovasi melakukan penelitian tindakan kelas berupa bagaimana peningkatan hasil belajar mengenal sandhangan aksara jawa melalui model flipped classroom berbantu media powerpoint interaktif pada kelas IV SD Negeri Mranggen 1 Tahun Ajaran 2020/2021. Dari rumusan masalah tersebut, maka tujuan dari penelitian ini ialah untuk megetahui peningkatan hasil belajar mengenal sandhangan aksara jawa melalui model flippedclassroom berbantu media powerpoint interaktif pada peserta didik kelas IV SD Negeri Mranggen 1 Tahun Ajaran 2020/2021

\section{METODE}

Penelitian ini merupakan penelitian tindakan kelas dengan menerapkan model Flipped Classroom berbantu media Powerpoint Interaktif. Penelitian dilakukan dengan 4 tahapan yaitu, perencanaan, pelaksanaan tindakan, pengamatan, dan relfeksi (Mawardi, 2020: 11-13). Subjek penelitian ini adalah peserta didik kelas IV SD Negeri Mranggen 1 Tahun Ajaran 2020/2021 yang berjumlah 25 peserta didik, terdiri dari 12 laki-laki dan 13 perempuan. Data yang digunakan berupa data kuantatif dan data kualitatif. Sumber data yang digunakan dalam penelitian antara lain sumber data primer peserta didik Kelas IV dan sumber data sekunder berupa dokumen, foto, RPP. Teknik pengumpulan data berupa dokumentasi, observasi dan tes. Teknik analisis data yang digunakan dalam penelitian ini yaitu reduksi, penyajian data dan kesimpulan. Indikator keberhasilan dalam penelitian tindakan kelas ini yaitu adanya peningkatan hasil belajar pada aspek pengetahuan dalam mengenal sandhangan aksara jawa dengan nilai telah mencapai KKM dan sekurang-kurangnya $80 \%$ peserta didik secara klasikal mengalami peningkatan hasil belajar.

\section{HASIL DAN PEMBAHASAN}

Penelitian ini dilakukan dalam tiga siklus, yaitu siklus I, siklus II, siklus II. Sebelum melaksanakan tindakan, peneliti melakukan observasi dan tes untuk mengetahui permasalahan yang terjadi dalam kegiatan pembelajaran di Kelas IV. Dalam hal ini, ditemukan adanya rendahnya hasil belajar dalam mengenal sandhangan aksara jawa pada peserta didik Kelas IV SD Negeri Mranggen 1. Hal tersebut, terbukti bahwa sebagian besar peserta didik masih memperoleh nilai di bawah KKM 70 dengan perolahan hasil rata-rata pratindakan sebesar 58,8 dengan presentase ketuntasan klasikal sebesar $40 \%$. Dari 25 peserta didik menunjukkan 10 peserta didik dinyatakan tuntas, dan 15 peserta didik dinyatakan tidak tuntas.

Pada siklus I, II, III, peneliti menerapkan model Flipped Classroom berbantu media powerpoint interaktif dengan langkah-langkah yang meliputi; 1) Guru merencanakan terperinci yang akan dipelajari peserta didik dirumah, 2) Memilih kegiatan sesuai dengan kebutuhan peserta didik, 3) mengintegrasikan aktivitas dirumah dan dikelas 4) Mempresentasikan hasil kerja peserta didik. Langkah-langkah model flippedclassroom tersebut dikemukakan oleh Basal (2015:34). Penggunaan media powerpoint interaktif dilakukan pada saat mengintegrasikan aktivitas dirumah dan dikelas dalam kegiatan pembelajaran.

Pada siklus I memperoleh rata-rata hasil belajar dengan sebesar 58,8 dengan presentase ketuntasan klasikal sebesar $40 \%$ bahwa sebanyak 17 peserta didik dinyatakan tuntas dan 8 peserta didik dinyatakan tidak tuntas. Pada siklus II presentase ketuntasan klasikal meningkat sebesar $68 \%$ dengan rata-rata nilai hasil belajar sebesar 73,4 bahwa 19 peserta didik dinyatakan tuntas KKM dan 6 peserta didik dinyatakan tidak tuntas. Pada siklus III adanya kenaikan presentase ketuntasan klasikal sebesar $88 \%$ 
dengen perolehan rata-rata hasil belajar 80,2, terdapat 22 peserta didik dinyatakan tuntas KKM dan 3 peserta didik dinyataka tidak memenuhi KKM. Pada siklus III, peneliti telah memenuhi dan mencapai indikator keberhasilan penelitian, maka kegiatan penelitian dihentikan pada siklus III. Berikut ini merupakan rekapitulasi hasil belajar peserta didik :

Tabel 1. Rekapitulasi Hasil Belajar Peserta Didik.

\begin{tabular}{cccccc}
\hline No. & Keterangan & Pratindakan & Siklus I & Siklus II & Siklus III \\
\hline 1 & Rata-rata & 58,8 & 73,4 & 76,8 & 80,2 \\
2 & $\begin{array}{c}\text { Presentase } \\
\text { Ketuntasan } \\
(\%)\end{array}$ & $40 \%$ & $68 \%$ & $76 \%$ & $88 \%$ \\
\hline
\end{tabular}

Berdasarkan hasil rekapitulasi pada tabel tersebut, terlihat adanya peningkatan hasil belajar peserta didik dalam mengenal sandhangan aksara jawa melalui model flipped classroom berbantu media powerpoint interaktif pada siklus I, siklus II, dan siklus III. Rujukan dalam pencapaian kompetensi tersebut sesuai dengan penelitian yang telah dilakukan oleh Rindaningsih, I., Hastuti, W.D. and Findawati, Y. (2019) dengan judul penelitian Desain Lingkungan Belajar yang Menyenangkan Berbasis Flipped Classroom di Sekolah Dasar. Pada artikel penelitian tersebut bahwa dengan menerapkan flipped classroom memberikan kesempatan kepada peserta didik untuk dapat terlibat dalam berpikir kritis, mandiri dengan memfasilitasi pembelajaran peserta didik dan lebih efektif untuk berinteraksi dengan dan belajar bersama teman-temannya. Selain itu penerapan model flipped classroom juga pernah diterapkan dalam penelitian yang dilakukan oleh Maolidah, I. S., Ruhimat, T., \& Dewi, L. (2017). Dengn judul "Efektivitas Penerapan Model Pembelajaran Flipped Classroom pada Peningkatan Kemampuan Berpikir Kritis Peserta didik". Pada penelitian tersebut menunjukkan bahwa dengan model pembelejaran flipped classroom efektif digunakan dalam meningkatkan kemampuan berpikir kritis sehingga meningkatkan hasil belajar peserta didik.

Penerapan media pembelajaran berupa powerpoint interaktif juga memiliki pengaruh dalam pencapaian kompetensi peserta didik. Sebab media powerpoint interaktif sebagai sarana yang digunakan untuk menyampaikan pesan dalam kegiatan pembelajaran. Hal tersebut sesuai dengan pendapat arsyad (2014:3) yang menyatakan pengunnaan media sebagai alat untuk menyampaikan atau mengantar pesan-pesan dalam kegiatan pembelajaran. Selain itu, penggunaan media powerpoint interaktif memiliki manfaat dalam tercapainya tujuan pembelajaran. Hal tersebut sesuai dengan pendapat Sanaky(2013:5) bahwa salah satu penggunaan media bermanfaat untuk sebagai bahan pengajaran yang lebih jelas maknanya dan dapat dipahami oleh pembelajar dalam menguasai tujuan pembelajaran. Penggunaan media powerpoint interaktif ini juga merujuk pada penelitian yang dilakukan oleh Elpira, N., \& Ghufron, A. (2015), bahwa pengaruh penggunaan media powerpoint terhadap Minat dan hasil belajar ipa peserta didik kelas IV SD. Jurnal Inovasi Teknologi Pendidikan, 2(1), 94-104. Menunjukkan hasil penelitian bahwa penggunaan media power point berpengaruh terhadap peningkatan minat dan hasil belajar peserta didik.

\section{SIMPULAN}

Berdasarkan hasil penelitian tindakan kelas yang telah dilakukan, dapat disimpulkan bahwa melalui model Flipped Classroom berbantu media Powerpoint interaktif dapat meningkatkan hasil belajar dalam mengenal sandhangan aksara jawa pada peserta didik kelas IV SD Negeri Mranggen 1. Adanya peningkatan hasil belajar aspek pengetahuan yang dilakukan peserta didik kelas IV semester II SD Negeri 
Mranggen 1 Tahun Pelajaran 2020/2021. Pada pratindakan ketuntasan klasikal sebesar $40 \%$. Siklus I memperoleh presentase ketuntasan klasikal 68\%, siklus II meningkat sebesar $76 \%$ dan, siklus III presentase ketuntasan klasikal meningkat sebesar $88 \%$.

Saran yang dapat diberikan peneliti setelah melakukan penelitian tindakan kelas dalam pembelajaran ialah 1) melalui model flipped classroom berbantu media powerpoint interaktif dapat diterapkan guru dalam kegiatan pembelajaran, 2) Dalam kegiatan belajar mengajar, guru dituntut untuk selalu kreatif.

\section{DAFTAR PUSTAKA}

Arsyad, Azhar. 2014. "Media Pembelajaran". Jakarta: PT Raja Grafindo Persada Aqib, Zainal. M.Chotibuddin. 2018. "Teori dan Aplikasi Penelitian Tindakan Kelas" (PTK). Yogyakarta: CV. Budi Utama.

Basal, A. (2015). The implementation of a flipped classroom in foreign language teaching. Turkish Online Journal of Distance Education, 16(4), 28-37

Dahar, Ratna Willis. 2011. "Teori-teori Belajar dan Pembelajaran". Jakarta: Erlangga

Elpira, N., \& Ghufron, A. (2015). Pengaruh penggunaan media powerpoint terhadap Minat dan hasil belajar ipa siswa kelas IV SD. Jurnal Inovasi Teknologi Pendidikan, 2(1), 94-104.

Maolidah, I. S., Ruhimat, T., \& Dewi, L. (2017). Efektivitas penerapan model pembelajaran flipped classroom pada peningkatan kemampuan berpikir kritis siswa. Educational Technologia, 1(2).

Mawardi, Pitalis. 2020. "Penelitian Tindakan Kelas, Penelitian Tindakan Sekolah Best Practise". Pasuruan: CV Penerbit Qiara Media.

Peraturan Gubenur Jawa Tengah (2013). Petunjuk pelaksanaan peraturan daerah provinsi jawa tengah nomor 9 tahun 2012 tentang bahasa, sastra, dan aksara jawa. Semarang: Penulis

Peraturan Daerah Provinsi Jawa Tengah (2012). Bahasa, Sastra, Dan Aksara Jawa. Semarang: Penulis

Rindaningsih, I., Hastuti, W. D., \& Findawati, Y. (2019). Desain Lingkungan Belajar yang Menyenangkan Berbasis Flipped Classroom di Sekolah Dasar. Proceedings of the ICECRS, 2(1), 41-47.

Sanaky, Hujair AH. Faizah. 2013. "Media Pembelajaran Interaktif-Inovatif". Yogyakarta: Kaukaba Dipantara.

Yulietri, F., \& Mulyoto, M. (2015). Model Flipped Classroom dan Discovery Learning Pengaruhnya Terhadap Prestasi Belajar Matematika Ditinjau Dari Kemandirian Belajar. Teknodika, 13(2). 